\title{
Artificial light and growth regulators on the in vitro etiolation of Cattleya labiata ${ }^{1}$
}

\author{
Luz artificial e reguladores de crescimento no estiolamento in vitro de Cattleya \\ labiata
}

\author{
Antonio Anderson de Jesus Rodrigues ${ }^{2}$, Eder de Oliveira Santos ${ }^{3}$, Roberto Jun Takane ${ }^{2}$ and Ana Cristina \\ Portugal Pinto de Carvalho ${ }^{4 *}$
}

\begin{abstract}
The technique of etiolation is widely used in the micropropagation of various plant species. The aim of this study was to evaluate growth and development in shoots of Cattleya labiata grown in vitro, as a function of growth regulators and the presence and absence of light. Stem segments, approximately $\pm 1.0 \mathrm{~cm}$ in height, were inoculated in test tubes containing $15.0 \mathrm{~mL}$ of MS culture medium supplemented with different concentrations of BAP $\left(0.0,2.0\right.$ and $\left.4.0 \mathrm{mg} \mathrm{L}^{-1}\right)$ and NAA $(0.0,1.0$ and $2.0 \mathrm{mg} \mathrm{L}^{-1}$ ), and in different growth environments (growth room, darkness and a photoperiod of 16 hours) in a completely randomised design. At 150 days, the following were evaluated: a) number of etiolated shoots; b) number of nodes per etiolated shoot; c) length of stem segment (cm); d) number of roots; and e) total seedling dry weight $(\mathrm{g})$. The highest mean values were achieved with the use of $4.0 \mathrm{mg} \mathrm{L}^{-1} \mathrm{BAP}$ and $1.0 \mathrm{mg} \mathrm{L}^{-1} \mathrm{NAA}$ for the number of etiolated shoots, and $2.0 \mathrm{mg} \mathrm{L}^{-1} \mathrm{NAA}_{\text {for the }}$ number of nodes per etiolated shoot in the absence of light. The length of stem segment was greater in the absence of light; in contrast, the number of roots and the total seedling dry weight were greater in a bright environment, irrespective of the growth regulator added to the culture medium. The etiolation of stem segments is a viable technique, as it provides features that are advantageous in the in vitro multiplication stage of the species.
\end{abstract}

Key words: Orchidaceae. Tissue culture. Photoperiod. 6-benzylaminupurine. Naphthaleneacetic acid.

RESUMO - A técnica do estiolamento é muito utilizada na micropropagação de várias espécies de plantas. Este trabalho teve como objetivo avaliar o crescimento e desenvolvimento de brotos de Cattleya labiata in vitro em função de reguladores de crescimento e da presença e ausência de luz. Segmentos caulinares, com aproximadamente $\pm 1,0 \mathrm{~cm}$ de altura, foram inoculados em tubos de ensaio contendo $15,0 \mathrm{~mL}$ de meio de cultura $\mathrm{MS}$, acrescido de diferentes concentrações de BAP $\left(0,0 ; 2,0\right.$ e $\left.4,0 \mathrm{mg} \mathrm{L}^{-1}\right)$, ANA $\left(0,0 ; 1,0\right.$ e $\left.2,0 \mathrm{mg} \mathrm{L}^{-1}\right)$ e ambientes de cultivo (sala de crescimento no escuro e com fotoperíodo 16 horas) em delineamento inteiramente casualizado. Aos 150 dias, avaliou-se: a) número de brotos estiolados; b) número de nós por broto estiolado; c) comprimento do segmento caulinar (cm); d) número de raízes; e, e) massa seca total da plântula (g). As maiores médias foram obtidas com a utilização de 4,0 $\mathrm{mg} \mathrm{L}^{-1}$ de BAP e 1,0 $\mathrm{mg} \mathrm{L}^{-1}$ de ANA para número de brotos estiolados e de $2,0 \mathrm{mg} \mathrm{L}^{-1}$ de ANA para número de nós por broto estiolado, em ausência de luz. O comprimento do segmento caulinar foi superior em ambiente sob ausência de luz; em contraste, o número de raízes e a massa seca total da plântula foram superiores em ambiente luminoso, independente do regulador de crescimento adicionado ao meio de cultivo. O estiolamento de segmentos caulinares é uma técnica viável, visto que proporcionou características vantajosas para a fase de multiplicação in vitro da referida espécie.

Palavras-chave: Orchidaceae. Cultura de tecidos. Fotoperíodo. 6-benzilaminupurina. Ácido naftaleno acético.

DOI: $10.5935 / 1806-6690.20170034$

* Autor para correspondência

Recebido para publicação em 04/11/2015; aprovado em 26/05/2016

'Extraído da Dissertação do primeiro autor, pesquisa desenvolvida no Laboratório de Cultura de Tecidos Vegetais/CNPAT/Embrapa

${ }^{2}$ Programa de Pós-Graduação em Fitotecnia/CCA/UFC, Av. Mister Hull, 2977, Bloco 805, Campus do Pici, Fortaleza-CE, Brasil, 60.356-000, andersonnjr@hotmail.com, robertotakane@gmail.com

${ }^{3}$ Programa de Pós-Graduação em Solos e Nutrição de Plantas/CCA/UFC, Av. Mister Hull, 2977, Bloco 807, Campus do Pici, Fortaleza-CE, Brasil, 60.356-000, ederolisan@gmail.com

${ }^{4}$ Laboratório de Cultura de Tecidos Vegetais/CNPAT/Embrapa, Rua Doutora Sara Mesquita, 2270, Bairro Pici, Fortaleza-CE, Brasil, 60.511-110, cristina.carvalho@embrapa.br 


\section{INTRODUCTION}

The family Orchidaceae has plants with greatly diversified flowers; there are about 800 genera containing 35,000 described species, valued for the beauty and durability of their flowers, which exhibit a wide variety of size, shape, colouration and fragrance (ROBERTS; DIXON, 2008).

The genus Cattleya includes epiphytic orchids, with more than 113 species found from Central America to the south of South America. They are considered the "Queens of the Orchids" because of their large, colourful and showy flowers (BERKA; VENTURIERI; TEIXEIRA, 2014; CABRERA; CÚDOM, 2013). Noteworthy among these species is Cattleya labiata, native to the northeast of Brazil. However, due to anthropic action, represented by predatory harvesting and the destruction of its habitat, it has been included by the Ministry of the Environment in the list of endangered species of Brazilian flora, along with 33 other orchids (BRASIL, 2008).

In nature, the propagation of orchids occurs from shoots or by the natural dissemination of the seeds contained in capsules. Under natural conditions, the greatest obstacle is the limited or lack of seed germination in the absence of mycorrhizae, which are essential for germination (RAMOS; CARNEIRO, 2007; SOARES et al., 2010). Considering the difficulty of seminiferous multiplication in orchids due to delay and the necessity of the presence of mycorrhizal fungi, in vitro germination and cultivation are necessary.

In this context, the technique of micropropagation is seen as an alternative for obtaining seedlings of high genetic and phytosanitary quality on a commercial scale (SILVA et al., 2007).

Tissue culture has provided for the preservation of species of orchids, such as those of the genera Cattleya and Brassavola, with the advantages of handling a large quantity of seedlings in a reduced space and under aseptic conditions (VILLA; PASQUAL; SILVA, 2014).

The plants present different and opposite phenotypic characteristics when developed in an environment with or without light. Seedlings that are submitted to the absence of luminosity undergo a special type of development known as skotomorphogenesis. Such seedlings develop stems that are elongated and whitish, short leaves, and distant internodes, and are unable to accumulate chlorophyll. Due to these characteristics, such seedlings are said to be etiolated (SUZUKI; KERBAUY; ZAFFARI, 2004; TAIZ; ZEIGER, 2013).
Etiolation has been used successfully in the micropropagation of other cultivated ornamental species. In the pineapple (Ananas comosus var. ananassoides), Dias et al. (2011b) obtained satisfactory results in the number of shoots using MS medium plus $0.5 \mathrm{mg} \mathrm{L}^{-1} \mathrm{BAP}$ (6-benzylaminopurine), with the largest etiolated shoots being produced in the absence of growth regulators. After 60 days of in vitro growth in the absence of light, Pinheiro et al. (2009) obtained good results for the number of shoots in anthurium (Anthurium andraeanum) var. IAC Eidibel in MS medium. Those researchers further found that there is no need for the addition of auxins to the culture medium to induce in vitro etiolation in this variety of anthurium.

In view of the need to obtain alternative methods for the propagation of native species threatened with extinction, and the lack of studies using growth regulators with in vitro etiolation, the aim was to evaluate the in vitro growth and development of shoots of Cattleya labiata as a function of growth regulators and the presence and absence of light.

\section{MATERIAL AND METHODS}

The experiment was carried out at the Laboratory for Plant Tissue Culture of Embrapa Agroindústria Tropical (CNPAT) in Fortaleza, in the State of Ceará, Brazil. Seedlings germinated in vitro were used, originating from seeds from the self-fertilisation of orchids of the species Cattleya labiata Lindl. from an orchid house located in Guaramiranga, Ceará. The seeds were inoculated and germinated in MS culture medium (MURASHIGE; SKOOG, 1962), supplemented with $30 \mathrm{~g} \mathrm{~L}^{-1}$ sucrose, and gelled with $5.5 \mathrm{~g} \mathrm{~L}^{-1}$ agar. The $\mathrm{pH}$ of the culture medium was adjusted to 5.8 before adding the agar, and the medium then autoclaved at $121{ }^{\circ} \mathrm{C}$ and $1 \mathrm{~atm}$ for 20 minutes.

During germination, the cultures were kept in a growth chamber under artificial light provided by coolwhite fluorescent lamps, at a light intensity of $30 \mu \mathrm{mol}$ $\mathrm{m}^{-2} \mathrm{~s}^{-1}$, a photoperiod of 16 hours and a temperature of $24 \pm 2{ }^{\circ} \mathrm{C}$ in MS medium, remaining for three months, until the experiment was set up. For the plant material to be uniform, the most developed seedlings were selected, having a vigorous appearance and dark green colouration, and containing 3 to 4 leaves. In a laminar flow chamber, their size was standardised by cutting at the apical region $(1.0 \pm 0.2 \mathrm{~cm})$ and their roots removed; they were inoculated in test tubes (size $150 \mathrm{~mm} \times 25 \mathrm{~mm}$ ) containing $15 \mathrm{~mL}$ of MS culture medium under the same conditions as in the in vitro germination phase (Figure 1).

The growth environment was a growth room under the same conditions as the in vitro germination phase. To 
Figure 1 - Explant used in the study: stem segment of Cattleya labiata Lindl. in a test tube containing MS medium. Bars $=1.0 \mathrm{~cm}$

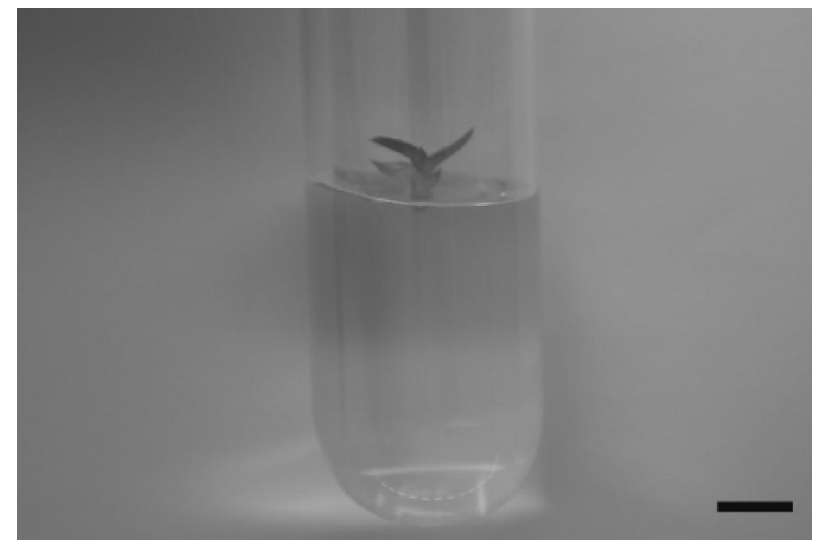

induce etiolation, part of the explants were kept in the growth room in the absence of light, maintaining the same temperature.

The experimental design was completely randomised, in a $2 \times 3 \times 3$ factorial scheme (two environments $\mathrm{x}$ three doses of BAP $\mathrm{x}$ three doses of NAA), with four replications per treatment. Each replication consisted of five tubes containing one explant per tube for analysis, totalling 72 lots and 18 treatments. The experimental unit used was one test tube with one explant. The treatments comprised MS medium plus three levels of BAP (with no BAP: 0.0, medium: 2.0 and high: $4.0 \mathrm{mg} \mathrm{L}^{-1}$ ), three levels of NAA (with no NAA: 0.0 , medium: 1.0 and high: $2.0 \mathrm{mg} \mathrm{L}^{-1}$ ) and two growth environments (presence and absence of light).

The evaluations were carried out after 150 days of in vitro growth, when the following were assessed: number of etiolated shoots per explant, length of stem segment $(\mathrm{cm})$, number of nodes per shoot, number of roots and total seedling dry weight $(\mathrm{g})$.

The data were submitted to analysis of variance using the Sisvar® statistical software (FERREIRA, 2014), and the means compared by F-test at $5 \%$ significance.

\section{RESULTS AND DISCUSSION}

The analysis of variance relative to the data shows, that for all the variables analysed, there was a significant effect at $1 \%$ from the environment (ENV) and its interaction with 6-benzylaminopurine (BAP) and naphthaleneacetic acid (NAA). Only for length of stem segment (LSS) was there a significant effect from the levels of BAP; there was a significant effect from the levels of NAA for all variables, except for the number of nodes per shoot $(\mathrm{NN} / \mathrm{S})$. There was no significant difference for the interaction between BAP and NAA, nor in the triple interaction including the factor environment, for any of the variables under analysis (Table 1).

At 150 days of in vitro growth, it was found that most of the explants maintained in the absence of light had the typical characteristics of etiolated and achlorophyllous

Table 1 - Summary of analysis of variance and coefficients of variation (CV) for number of etiolated shoots per explant (NS/E), number of nodes per etiolated shoot (NN/S), length of stem segment (LSS) in $\mathrm{cm}$, number of roots (NR) and total seedling dry weight in $\mathrm{g}$ (TSDW), in etiolated nodal segments of Cattleya labiata grown at different levels of BAP and NAA in the presence and absence of light, at 150 days of in vitro growth

\begin{tabular}{lcccccc}
\hline \multirow{2}{*}{ Source of variation } & DF & \multicolumn{5}{c}{ MS } \\
\cline { 3 - 6 } & & NS/E & NN/S & LSS & NR & TSDW \\
\hline Environment (ENV) & 1 & $9.58^{* *}$ & $1296.81^{* *}$ & $16.86^{* *}$ & $742.00^{* *}$ & $0.0487^{* *}$ \\
BAP (BAP) & 2 & $0.03^{\text {ns }}$ & $0.26^{\text {ns }}$ & $0.86^{*}$ & $0.03^{\text {ns }}$ & $0.0000^{\text {ns }}$ \\
NAA (NAA) & 2 & $7.95^{* *}$ & $0.30^{\text {ns }}$ & $1.04^{* *}$ & $4.27^{* *}$ & $0.0046^{* *}$ \\
ENV x BAP & 2 & $9.49^{* *}$ & $1.25^{* *}$ & $2.17^{* *}$ & $1.61^{* *}$ & $0.0018^{* *}$ \\
ENV x NAA & 2 & $7.84^{* *}$ & $1.26^{* *}$ & $5.11^{* *}$ & $4.24^{* *}$ & $0.0028^{* *}$ \\
BAP x NAA & 4 & $0.06^{\mathrm{ns}}$ & $0.27^{\mathrm{ns}}$ & $0.20^{\mathrm{ns}}$ & $0.12^{\mathrm{ns}}$ & $0.0000^{\mathrm{ns}}$ \\
ENV x BAP x NAA & 4 & $0.05^{\mathrm{ns}}$ & $0.32^{\mathrm{ns}}$ & $0.33^{\mathrm{ns}}$ & $0.08^{\mathrm{ns}}$ & $0.0000^{\mathrm{ns}}$ \\
Residual & 54 & 0.48 & 0.36 & 0.18 & 0.30 & 0.0000 \\
\hline CV $(\%)$ & & 29.04 & 25.00 & 16.96 & 30.62 & 14.36 \\
\hline
\end{tabular}

$\mathrm{DF}=$ Degrees of freedom; CV = Coefficient of variation; MS = Mean square; * and ** Significant at 0.05 and 0.01 probability respectively; ${ }^{\text {ns }}$ - not significant by F-test 
plants, such as whitish and translucent stems, small leaves whose blades had not expanded, and a greater internodal distance (Figure 2A). These explants produced shoots at the base or from the nodes, with these shoots also presenting the phenotype of etiolated plants common to the process of skotomorphogenesis. Taiz and Zeiger (2013) report that the occurrence of these characteristics in plants grown in the dark over long periods is due to inhibition of the development of proplastids which, without the bright stimulus, instead of becoming chloroplasts, develop into etioplasts, which do not synthesise the photosynthetic enzymes and pigments necessary to the photosynthetic machinery.

The cultures kept in an environment of artificial light showed normal photosynthetic development, as seen by the greenish colouration, when compared to the etiolated cultures (Figure 2B). However, there was a smaller distance between nodes, which did not allow their separation nor their being counted.

The number of etiolated shoots was greater for most levels of growth regulator in the dark (Table 2A). Analysing the growth environment in the presence of light, there was no difference for levels of NAA; however, a significance was seen for BAP, and the mean level of $2.0 \mathrm{mg} \mathrm{L}^{-1}$ proved to be beneficial, (2.11 shoots explant $\left.{ }^{-1}\right)$. In relation to the growth environment in the absence of light, the use of high levels of BAP (4.0 $\mathrm{mg} \mathrm{L}^{-1}$ ) gave the highest number of shoots (2.36), although it did not differ from the other doses of BAP;
Figure 2 - Seedlings of Cattleya labiata Lindl. grown in the absence of light (A) and in the presence of light (B), at 150 days of in vitro growth. Bars $=1.0 \mathrm{~cm}$

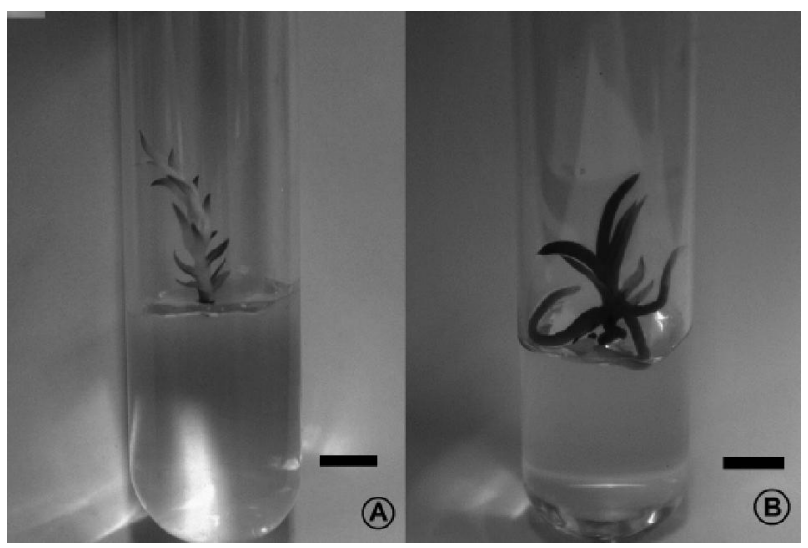

with no BAP $\left(0.0 \mathrm{mg} \mathrm{L}^{-1}\right)$, there was an average of 2.21 etiolated shoots, showing it to be more economical. For the factor NAA, the best responses were obtained in the presence of an average level of $1.0 \mathrm{mg} \mathrm{L}^{-1}$ (2.51 shoots explant $^{-1}$ ) (Table 2A).

In the absence of light, the increase in BAP concentration in the culture medium did not result in a greater number of shoots in Cattleya labiata. Ramos and Carneiro (2007) and Soares et al. (2010), studying Cattleya x mesquitae and Laelia crispata respectively, obtained an increase in shoots in the absence of BAP and

Table 2 - Number of shoots per explant, number of nodes per shoot, and length of stem segment, in Cattleya labiata in different growth environments (presence and absence of light) and different levels of BAP and NAA), at 150 days of in vitro growth

\begin{tabular}{|c|c|c|c|c|c|c|}
\hline \multicolumn{7}{|c|}{ (A) Number of etiolated shoots per explant } \\
\hline \multirow{2}{*}{ Environment } & \multicolumn{3}{|c|}{$\mathrm{BAP}\left(\mathrm{mg} \mathrm{L}^{-1}\right)$} & \multicolumn{3}{|c|}{ NAA $\left(\mathrm{mg} \mathrm{L}^{-1}\right)$} \\
\hline & 0 & 2 & 4 & 0 & 1 & 2 \\
\hline Light & $1.64 \mathrm{bB}$ & $2.11 \mathrm{aA}$ & $1.38 \mathrm{bB}$ & $1.74 \mathrm{aB}$ & $1.77 \mathrm{aB}$ & $1.68 \mathrm{aB}$ \\
\hline Dark & $2.21 \mathrm{aA}$ & $1.97 \mathrm{aB}$ & $2.36 \mathrm{aA}$ & $1.97 \mathrm{bA}$ & $2.51 \mathrm{aA}$ & $2.28 \mathrm{aA}$ \\
\hline \multicolumn{7}{|c|}{ (B) Number of nodes per etiolated shoot } \\
\hline \multirow{2}{*}{ Environment } & \multicolumn{3}{|c|}{$\operatorname{BAP}\left(\mathrm{mg} \mathrm{L}^{-1}\right)$} & \multicolumn{3}{|c|}{$\mathrm{NAA}\left(\mathrm{mg} \mathrm{L}^{-1}\right)$} \\
\hline & 0 & 2 & 4 & 0 & 1 & 2 \\
\hline Light & $0.00 \mathrm{aB}$ & $0.00 \mathrm{aB}$ & $0.00 \mathrm{aB}$ & $0.00 \mathrm{aB}$ & $0.00 \mathrm{aB}$ & $0.00 \mathrm{aB}$ \\
\hline Dark & $3.98 \mathrm{aA}$ & $3.79 \mathrm{bA}$ & $3.93 \mathrm{aA}$ & $3.82 \mathrm{bA}$ & $3.74 \mathrm{bA}$ & $3.97 \mathrm{aA}$ \\
\hline \multicolumn{7}{|c|}{ (C) Length of stem segment $(\mathrm{cm})$} \\
\hline \multirow{2}{*}{ Environment } & \multicolumn{3}{|c|}{$\operatorname{BAP}\left(\mathrm{mg} \mathrm{L}^{-1}\right)$} & \multicolumn{3}{|c|}{$\operatorname{ANA}\left(\mathrm{mg} \mathrm{L}^{-1}\right)$} \\
\hline & 0 & 2 & 4 & 0 & 1 & 2 \\
\hline Light & $1.90 \mathrm{aB}$ & $1.97 \mathrm{aB}$ & $1.86 \mathrm{aB}$ & $1.87 \mathrm{aA}$ & $1.84 \mathrm{abB}$ & $1.68 \mathrm{bB}$ \\
\hline Dark & $2.65 \mathrm{aA}$ & $2.16 \mathrm{bA}$ & $2.22 \mathrm{bA}$ & $1.96 \mathrm{bA}$ & $2.09 \mathrm{bA}$ & $2.64 \mathrm{aA}$ \\
\hline
\end{tabular}


in the dark. Suzuki, Kerbauy and Zaffari (2004) found that the endogenous level of cytokinins in an environment with no light is greater than in the presence of light in Cattleya fimbriatum. This phenomenon may also have occurred with the explants from Cattleya labiata grown in a dark environment, i.e. the endogenous level of cytokinins, and the addition of BAP to the culture medium, may have resulted in interference to the formation of new shoots. In the dark, the addition of NAA to the culture medium proved suitable for the formation of shoots on the explants, as this is possibly due the ratio of auxin to cytokinin that directed the plant metabolism towards a greater production of shoots. The addition of BAP also resulted in an increase in the number of etiolated shoots when used at the medium concentration of $2.0 \mathrm{mg} \mathrm{L}^{-1}$ in the presence of light.

The addition of the high level of NAA $\left(2.0 \mathrm{mg} \mathrm{L}^{-1}\right)$ to the culture medium in the absence of light resulted in a significant increase in the number of nodes per etiolated shoot (Table 2B). In the micropropagation of Cattleya $\mathrm{x}$ mesquita, Ramos and Carneiro (2007) obtained an average of 3.72 nodes per shoot under the same conditions, $2.0 \mathrm{mg} \mathrm{L}^{-1} \mathrm{NAA}$, and in the dark. In the present study, a production of 2.28 nodes per shoot was seen under the same conditions. This is because some of the nodes produced by the explants had no buds at the time of evaluation.

In this study, the greatest production of nodes with the use of BAP was obtained both at the high level of $4.0 \mathrm{mg} \mathrm{L}^{-1}$ and with no BAP $\left(0.0 \mathrm{mg} \mathrm{L}^{-1}\right)$, producing 3.93 and 3.98 nodes per shoot respectively. These results partially agree with those obtained by Soares et al. (2010) where, in the absence of the cytokinin BAP, they observed the highest average production of nodes per shoot (7.31) in Laelia crispata. For the characteristic in question, not adding growth regulators when obtaining seedlings by micropropagation is advantageous to a reduction in production costs. Also in relation to the number of nodes per etiolated shoot, it was found that with light the etiolated shoots presented no perceptible nodes for counting, even with the addition of BAP and NAA to the culture medium. This is due to the growth and the organised and repetitive development in the formation of the organ in the plant, which presents a short distance between formed nodes, making a direct count impossible macroscopically.

The length of the stem segments varied between environments for each of the growth regulators. Values were higher in the absence of light (Table 2C). It can be seen that the BAP has a reducing effect compared to the medium with no addition of this cytokinin in the dark; this was represented by a drop in mean values for length as the concentration of the growth regulator increased. For the factor NAA, a positive effect was seen with the increase in concentration of this auxin in the culture medium in a dark environment, obtaining an average length of $2.64 \mathrm{~cm}$ at the high dose of $2.0 \mathrm{mg} \mathrm{L}^{-1}$.

The observed behaviour for the length of the stem segment can be attributed to the ability of cytokinins to modify apical dominance and promote growth of the lateral buds (TAIZ; ZEIGER, 2013). Mok, Martin and Mok (2000) mention that supplementing the culture medium with BAP causes breaking of apical dominance, favouring the emission of new shoots.

Studies carried out by Dias et al. (2011a) showed that an increase in BAP in the culture medium caused a reduction in the length of the shoots in Ananas comosus var. ananassoides. The same was found in this study, where it was seen that the addition of BAP resulted in a decrease in the length of the stem segments in the absence of light. However, the addition of NAA had the opposite effect, noted by a longer length for the stem segments as the dose of NAA increased in the absence of light.

On the other hand, no differences were seen when using the various concentrations of BAP in the culture medium in a bright environment; increases in the doses of NAA did not benefit growth in the presence of light, producing smaller nodes. Moreira et al. (2003) state that the length of the stem segment is an important variable, since it is directly related to the number of nodes that will be formed in the new shoots when placed in a bright environment.

In the in vitro cultivation of Catasetum fimbriatum, Suzuki, Kerbauy and Zaffari (2004) obtained larger seedlings when these were kept in the absence of light, irespective of the growth regulators and doses used.

For the number of roots, the interaction between NAA levels and the environment was significant by F-test (Table 3). The greatest number of roots was obtained in the interaction between the high level of NAA (2.0 $\left.\mathrm{mg} \mathrm{L}^{-1}\right)$ and the bright environment, with an average production of 3.32 roots, whereas in the dark environment and with the same dose of auxin, the average production was 1.26 roots.

In the micropropagation of Ananas comosus, Piza, Lima and Brasil (2001) found that the culture medium supplemented with $2.0 \mathrm{mg} \mathrm{L}^{-1}$ NAA favoured rooting in the species.

The usual concentration of NAA used with different plant species is less than $0.5 \mathrm{mg} \mathrm{L}^{-1}$; however, there may be variations in the results of these studies due to genetic differences (GRATTAPAGLIA; MACHADO, 1998). This is because plant species respond differently to the application of growth regulators as a function of the endogenous auxin/ cytokinin content (DIAS et al., 2011b). 
Table 3 - Number of roots and total seedling dry weight, in Cattleya labiata in different growth environments (presence and absence of light and different levels of BAP and NAA), at 150 days of in vitro growth

\begin{tabular}{|c|c|c|c|c|c|c|}
\hline \multicolumn{7}{|c|}{ (A) Number of roots } \\
\hline \multirow{2}{*}{ Environment } & \multicolumn{3}{|c|}{$\mathrm{BAP}\left(\mathrm{mg} \mathrm{L}^{-1}\right)$} & \multicolumn{3}{|c|}{$\mathrm{NAA}\left(\mathrm{mg} \mathrm{L}^{-1}\right)$} \\
\hline & 0 & 2 & 4 & 0 & 1 & 2 \\
\hline Light & $2.42 \mathrm{aA}$ & $2.35 \mathrm{aA}$ & $2.17 \mathrm{bA}$ & $2.44 \mathrm{bA}$ & $2.98 \mathrm{abA}$ & $3.32 \mathrm{aA}$ \\
\hline Dark & $0.34 \mathrm{aB}$ & $0.45 \mathrm{aB}$ & $0.38 \mathrm{aB}$ & $0.79 \mathrm{bB}$ & $0.85 \mathrm{bB}$ & $1.26 \mathrm{aB}$ \\
\hline \multicolumn{7}{|c|}{ (B) Total seedling dry weight (g) } \\
\hline \multirow{2}{*}{ Environment } & \multicolumn{3}{|c|}{$\mathrm{BAP}\left(\mathrm{mg} \mathrm{L}^{-1}\right)$} & \multicolumn{3}{|c|}{$\mathrm{NAA}\left(\mathrm{mg} \mathrm{L}^{-1}\right)$} \\
\hline & 0 & 2 & 4 & 0 & 1 & 2 \\
\hline Light & $0.023 \mathrm{cA}$ & $0.031 \mathrm{bA}$ & $0.041 \mathrm{aA}$ & $0.018 \mathrm{bA}$ & $0.036 \mathrm{aA}$ & $0.039 \mathrm{aA}$ \\
\hline Dark & $0.008 \mathrm{aB}$ & $0.009 \mathrm{aB}$ & $0.008 \mathrm{aB}$ & $0.007 \mathrm{aB}$ & $0.008 \mathrm{aB}$ & $0.009 \mathrm{aB}$ \\
\hline
\end{tabular}

Mean values followed by the same letter, lowercase on a line and uppercase in a column, within each variable differ by Tukey's test at 5\% probability

Both controls demonstrated that light favours in vitro rooting in Cattleya labiata. In the presence of light, the highest level of BAP tested had a negative effect on the number of formed roots. Whereas under the same conditions, the addition of NAA to the culture medium favoured root development.

Auxins and cytokinins have opposite effects on the root development of in vitro cultures in environments with the presence of light. While a higher concentration of auxins favours root formation, a higher concentration of cytokinins inhibits it (LEMOS, 2010).

There were significant differences between the interactions BAP x Environment and NAA x Environment for total seedling dry weight. The greatest accumulations of seedling dry weight were seen in the culture medium with high levels of growth regulator in the bright environment. The high levels of BAP (4.0 $\left.\mathrm{mg} \mathrm{L}^{-1}\right)$ and NAA $\left(2.0 \mathrm{mg} \mathrm{L}^{-1}\right)$ promoted an increase in biomass of $0.041 \mathrm{~g}$ and $0.039 \mathrm{~g}$ respectively (Table $3 \mathrm{~B}$ ).

In studies into the increase in total dry weight in seedlings of Oncidium leuchochilum in an MS nutrient medium containing $1.0 \mathrm{mg} \mathrm{L}^{-1} \mathrm{BAP}$ and $0.25 \mathrm{mg} \mathrm{L}^{-1}$ NAA in the presence of light, Scheidt et al. (2009) obtained seedlings with an average of $0.45 \mathrm{~g}$ of total dry weight. Souto et al. (2010), studying the effects of naphthaleneacetic acid on the in vitro development of Cattleya bicolor, recorded approximate mean values of $0.025 \mathrm{~g}$ dry weight in seedlings of the same species, with the use of $2.0 \mathrm{mg} \mathrm{L}^{-1}$ of NAA.

Both the species and the varieties present varied and different responses to the use of growth regulators (MITRA; BOSE, 1991).
Seedlings grown in the presence of light had higher mean values for total dry weight at all levels, irrespective of the growth regulator, when compared to those grown in the dark.

There was no increase in seedling weight in the presence of BAP or NAA when the cultures were grown in the absence of light. However, the opposite was seen in cultures kept under light, with increases in seedling dry weight.

These observations emphasize the essential role of the photosynthetic process in obtaining energy, and in the formation of the carbon skeletons necessary for plant growth and development (TAIZ; ZEIGER, 2013), whereas etiolation is an evolutionary mechanism in which the energy contained in the plant tissues is used for elongation as an adaptive strategy in the search for light (KERBAUY; CHAER, 2011). In the first process, plant growth occurs in an organised way in the width and length of all the organs, while with etiolation, growth in the length of the stem is given priority to the detriment of width; the leaves are small and little developed, resulting in a lesser amount of dry weight, compared to seedlings grown in a bright environment.

The production of in vitro shoots from orchids of the species Cattleya labiata by means of the etiolation of nodal seedling segments is therefore a viable technique, since it affords advantageous characteristics during the phase of in vitro multiplication of the species, such as the formation of more vigorous shoots of medium size, suggesting greater possibilities for the regeneration and formation of new explants. 


\section{CONCLUSIONS}

1. The number of etiolated shoots in seedlings of Cattleya labiata is greater in the absence of light, both using a high level of BAP $\left(4.0 \mathrm{mg} \mathrm{L}^{-1}\right)$ and in the absence of NAA $\left(0.0 \mathrm{mg} \mathrm{L}^{-1}\right)$; the same is seen in the presence of medium $\left(1.0 \mathrm{mg} \mathrm{L}^{-1}\right)$ and high $\left(2.0 \mathrm{mg} \mathrm{L}^{-1}\right)$ levels of NAA;

2. The presence of NAA induces a greater number of nodes, longer main shoots and an increase in the number of roots, while encouraging the in vitro etiolation of nodal segments in the orchid (Cattleya labiata);

3. The addition of high levels of BAP $\left(4.0 \mathrm{mg} \mathrm{L}^{-1}\right)$ and NAA (2.0 mg L $\left.\mathrm{m}^{-1}\right)$ increases seedling dry weight in the in vitro cultivation of the orchid (Cattleya labiata) in the presence of light.

\section{ACKNOWLEDGMENTS}

The authors wish to thank Embrapa Agroindústria Tropical and the Universidade Federal do Ceará (UFC) for their assistance in this research. Thanks also go to FUNCAP for the scholarships grants.

\section{REFERENCES}

BERKA, M. G.; VENTURIERI, G. A.; TEIXEIRA, T. N. Development of Cattleya amethystoglossa $x$ nobilior in simplified culture media. Acta Scientiarum. Agronomy, v. 36, n. 4, p. 425-428, 2014.

BRASIL. Ministério do Meio Ambiente. Instrução normativa de setembro de 2008. Disponível em: <http://www.estadao.com.br/ ext/especiais/2008/09/extint.pdf>. Acesso em: 25 maio 2016.

CABRERA, M. G.; CÚDOM, M. A. Ocurrencia de Lasiodiplodia theobromae en Cattleya spp. en Corrientes, Argentina. Summa Phytopathologica, v. 39, n. 2, p. 143-143, 2013.

DIAS, M. M. et al. Concentrações de reguladores vegetais no estiolamento in vitro de ananás do campo. Semina: Ciências Agrárias, v. 32, n. 2, p. 513-520, 2011 b.

DIAS, M. M. et al. Reguladores de crescimento na propagação in vitro de abacaxizeiro ornamental. Revista Brasileira de Ciências Agrárias, v. 6, n. 3, p. 383-390, 2011a.

FERREIRA, D. F. Sisvar: a guide for its bootstrap procedures in multiple comparisons. Ciência e Agrotecnologia, v. 38, n. 2, p. 109-112, 2014.

GRATTAPAGLIA, D.; MACHADO, M. A. Micropropagação. In: TORRES, A. C.; CALDAS, L. S. (Ed.). Técnicas e aplicações da cultura de tecidos de plantas. Brasília, DF: ABCTP. EMBRAPA-CNPH, 1998. p. 99-169.

KERBAUY, G. B.; CHAER, L. Micropropagação comercial de orquídeas conquistas, desafios e perspectivas. In: GERALD,
L. T. S. (Org.). Biofábrica de plantas: produção industrial de plantas in vitro. 1. ed. São Paulo: Antiqua, 2011. p. 177-205.

LEMOS, E. E. P. Organogênese. In: BARRUETO CID, L. P. (Ed.). Cultivo in vitro de plantas. 1 ed. Brasília: EMBRAPA, 2010. v. 1, p. 103-127.

MITRA, S. K.; BOSE, T. K. Metabolic changes during adventitious root formation in ethrel and IBA treated cutting of litchi. The Indian Journal of Horticulture, v. 48, n. 2, p. 105-107, 1991.

MOK, M. C.; MARTIN, R. C.; MOK, D. W. S. Cytokinins: biosynthesis, metabolism and perception. In vitro Cellular \& Developmental Biology Plant, v. 36, n. 1, p. 102-107, 2000.

MOREIRA, M. A. et al. Estiolamento na micropropagação do abacaxizeiro cv. Pérola. Ciência e Agrotecnologia, v. 27, n. 5, p.1002-1006, 2003.

MURASHIGE, T.; SKOOG, F. A revised medium for rapid growth and biossays with tobbaco tissue cultures. Physiologia Plantarum, v. 15, n. 1, p. 473-497, 1962.

PINHEIRO, M. V. M. et al. Micropropagação de antúrio 'IAC Eidibel' por meio da indução ao estiolamento e regeneração de plantas. Revista Brasileira de Horticultura Ornamental, v. 15 , n. 2, p. 133-142, 2009.

PIZA, I. M. T.; LIMA, G. P. P.; BRASIL, O. G. Reguladores vegetais na micropropagação do abacaxizeiro. Revista Ceres, v. 48 , n. 280, p. 681-690, 2001.

RAMOS, T. V.; CARNEIRO, I. F. Multiplicação “in vitro" de Cattleya $x$ mesquitae pelo método de estiolamento de segmentos caulinares. Pesquisa Agropecuária Tropical, v. 37, n. 1, p. 10-15, 2007.

ROBERTS, D. L.; DIXON, K. W. Orchids. Current Biology, v. 18 , n. 8 , p. $325-329,2008$.

SCHEIDT, G. N. et al. Multiplicação in vitro de Oncidium leucochilum (Orchidaceae) em diferentes sistemas de cultivo. Biociências, v. 17, n. 1, p. 82-85, 2009.

SILVA, J. V. et al. Aclimatização "ex vitro" de mudas de antúrio em diferentes substratos. Revista Ciência Agronômica, v. 38, n. 2, p. 188-191, 2007.

SOARES, J. D. R. et al. Estiolamento e luz artificial no cultivo in vitro de orquídeas nativa e híbrida. Ciencia Rural, v. 40, n. 9, p. 1941-1947, 2010.

SOUTO, J. S. et al. Efeitos do ácido naftalenoacético no desenvolvimento in vitro de Cattleya bicolor Lindl. (Orchidaceae). Revista Brasileira de Biociências, v.8, n. 2, p. $179-185,2010$.

SUZUKI, R. M.; KERBAUY, G. B.; ZAFFARI, G. R. Endogenous hormonal levels and growth of dark-incubated shoots of Catasetum fimbriatum. Journal of Plant Physiology, v. 161, p. 929-935, 2004.

TAIZ, L.; ZEIGER, E. Fisiologia Vegetal. 5. ed. Artmed: Porto Alegre, 2013, $918 \mathrm{p}$.

VILLA, F.; PASQUAL, M.; SILVA, E. F. Micropropagação de híbridos de orquídeas em meio knudson com adição de vitaminas do meio ms, benzilaminopurina e carvão ativado. Semina: Ciências Agrárias, v. 35, n. 2, p. 683-694, 2014. 